\title{
Analysis of the Effectiveness of M-Learning Goes (Guide Objective Elementary School) in Elementary School
}

\author{
Desi Novianti ${ }^{1, *}$, Dewi Anjani ${ }^{1}$, Hilda Hilaliyah² \\ ${ }^{1}$ Department of Informatics, Universitas Indraprasta PGRI,Jakarta, Indonesia \\ ${ }^{2}$ Department of Education, Universitas Indraprasta PGRI, Jakarta, Indonesia
}

Received December 29, 2019; Revised February 20, 2020; Accepted February 26,2020

Copyright $\bigcirc 2020$ by authors, all rights reserved. Authors agree that this article remains permanently open access under the terms of the Creative Commons Attribution License 4.0 International License

\begin{abstract}
Effectiveness is part of the quality of the software. The level of system planning will determine the successful implementation of the system in an educational institution. The higher the level of increase, the higher the functionality and usability of the system. This research was made to measure the efficiency of learning media through GOES (Guide Objective Elementary School) mobile learning (m-learning) in elementary schools in DKI Jakarta. With this GOES m-learning, it can make it easier for students to get teaching material because students cannot attend school. Also besides, it can be a liaison that provides information about the development of children to school and without having to come to school. The research sites are in the 15th, 19th, 20th, 21st and 22nd DKI Elementary Schools. This research is descriptive in nature using a questionnaire that is tested using the t-test. The total questionnaire processed was 150 questionnaires out of 540 questionnaires distributed to teachers, distributed and students. The results of the questionnaire show that GOES m-learning can improve students' learning and facilitate students' assignments even if they are not present at school.
\end{abstract}

Keywords M-learning, Elementary School, Absent, Goes, Mobile Application

\section{Introduction}

Today, the development and progress in the field of science and technology are growing rapidly. Because of the development of the progress of science and technology, humans can create sophisticated tools and equipment for various activities so that in their life activities various facilities enable their activities to be more effective and efficient.

One tool that is used and is often used is a cellphone. Mobile can not only be used as a means of communication but also can be used as a media of learning in education. It is not a new thing if teachers and students currently use learning assistance by using mobile phones.

To complement the learning support facilities, a learning media designed using a computer and internet-based on mobile is called m-learning. M-learning is defined as a method of learning and teaching that uses electronic media (connected to the internet connection) to deliver material and guidance based on mobile. There is also a definition of M-learning as a form of distance learning that is done through internet media. M-learning makes it easy for users to get a lot of material from the internet as well as mobile-based.

Elementary School students in grades 4 through 6 already have a higher learning load compared to the classes below, so that they require more information. Obstacles that are meeting while the student cannot be present in the class. The effect of this absence affects Teaching and Learning activities to a lesser extent, which causes problems with learning material being left behind.

M-learning GOES is an interactive learning system that involves interactions between teachers, students, and parents. Applications that rely on the Android operating system are intended to facilitate teaching and learning activities. This application offers a learning system that utilizes information technology so that Teaching and Learning activities can be done anytime and anywhere.

Effectiveness is one part of software quality [1]. The level of effectiveness of a system will determine the successful implementation of the system or software in a basic education environment. The higher the level of effectiveness and efficiency, the more functionality and usability of the system increases. Based on ISO / ICE 
9126 regarding software quality, the effectiveness of software can be measured from several factors such as work effectiveness, frequency of errors, completion of work [1]

This research was made to measure the efficiency of learning media through GOES mobile learning (m-learning) in elementary schools in DKI Jakarta. With this GOES m-learning, it can make it easier for students to get teaching material because students cannot attend school. Also besides, it can be a liaison that provides information about the development of children to school and without having to come to school.

\section{Literature Review}

\section{GOES (Guide Objective Elementary School)}

GOES M-learning is a more interactive system that involves teachers, students, and parents of students. Activities undertaken in this application include the teacher uploading materials, exercises, sample exams, and homework. Students can see the material; do the exercises, sample exams and homework. In this application, the teacher will also enter the collection time for homework, so students and parents will be reminded of the time indicated for doing homework have not been done.

The application will sound a warning alarm on the smartphone guardians of students and parents if the student has not finished the homework. The alarm will stop when the student input data that they have finished.

This system, too, will provide reports to student guardians on the results obtained by students at school, so that there are no more correction errors between teachers and students from the results of lesson evaluation.

Some examples of interface from GOES m-learning are as follows:

a. Login interface

This interface is useful for entering username and password input. For login, it will be given a NIP / NIS which is a unique code created by the system. Here is a display from login interface:
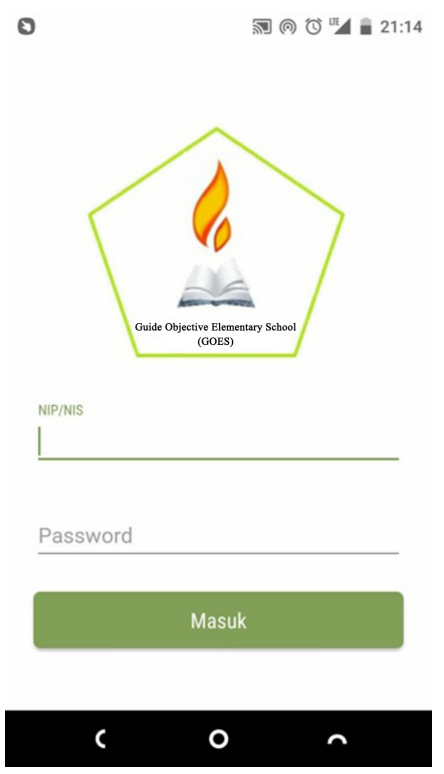

Figure 1. Login Interface

b. Main interface

This interface is useful for viewing subjects in the application and each subject will contain material, sample questions, exercises, and homework assignments. Below this is the main interface display:

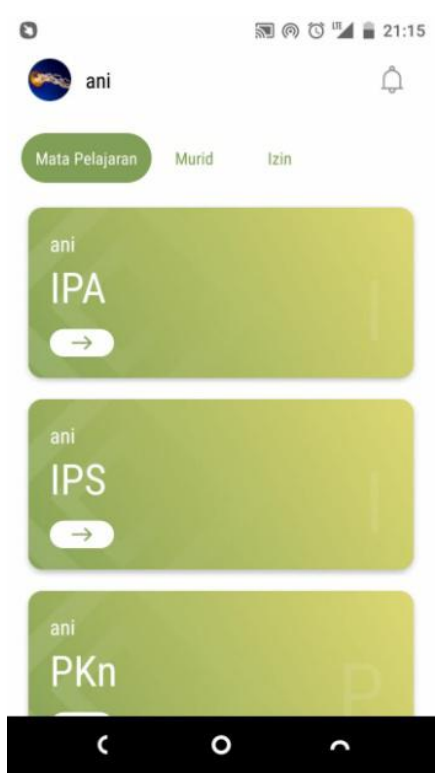

Figure 2. Main interface 


\section{Effectiveness}

Effectiveness is a measure that states how far targets (quantity, quality and time) have been achieved [2]. Where the greater the percentage of targets achieved, the higher the effectiveness. While [3] explains that effectiveness is the ability to choose the right goals or the right equipment for achieving the goals set. The effectiveness of the level of ability to achieve goals appropriately and well [4] .

Effectiveness is the range of effort of a program as a system with certain resources and means to meet its goals and objectives without disabling the means and resources and without putting undue pressure on their implementation[5]. In learning, careful planning is needed, making learning tools, choosing strategies, media, and techniques, learning models, and learning evaluations, all of which are mutually sustainable. The need to use effective and innovative learning models so that learning can be varied and run smoothly. The use of the learning model is also adapted to the material to be taught so that the compatibility between the two and all the components is appropriate.

Measurement of learning effectiveness must always be linked to the achievement of learning objectives. Indicators that can be used to determine the effectiveness of learning, namely:

1. Accuracy in mastering behavior

2. Speed of performance

3. Compliance with procedures,

4. Performance quantity

5. The quality of the final results

6. The degree of transfer of learning

7. Retention rate.

Learning effectiveness is measured by the ratio between effectiveness and the amount of time spent by students and/or the amount of learning costs and/or learning resources used. Thus there are three indicators to determine the level of effectiveness, namely:

1. Time

2. What is the amount of time required by students to achieve goals that have been set

3. Personnel

4. How many personnel are involved in implementing learning?

5. Learning resources

6. How to use learning resources that are designed for learning

The answers to these questions will give an idea of the level of efficiency of the learning program.

\section{Effectiveness Approach}

The effectiveness approach is used to measure the extent to which the activity is effective. There are several approaches used for effectiveness, namely:

a. Target Approach
This approach is used to measure the extent to which an institution has succeeded in realizing the goals to be achieved. In this approach, the target approach uses a measurement of effectiveness that starts with identifying organizational goals and measuring the level of organizational success in achieving these goals. In addition to achieving goals/targets, the time factor for implementation is also always used in measuring effectiveness. Therefore the effectiveness always contains an element of implementation time. The goal is reached with the right time so the program is effective [6].

b. Source Approach

This approach measures effectiveness based on the success of an institution in obtaining the various sources it needs and also maintains the situation and system, this is done so that it can run effectively. This approach is based on the theory of the openness of an institution's system to its environment, because an institution has an even relationship with its environment where from the environment sources can be obtained from the institution's input and the resulting output is also cleared to its environment[6].

c. Process Approach

This approach is used as the efficiency of an internal institution. In an effective institution, the internal process runs smoothly where the activities of the existing parts can run in a coordinated manner. This approach does not pay attention to the environment but focuses on activities carried out on sources owned by institutions that describe the level of efficiency of the institution [6]

\section{Method}

\section{Research Type}

This research uses quantitative, quantitative research as a study that contains an explanation (description) of a valid and objective phenomenon. In this study, the hypothesis test was done using the t-test [7].

\section{Research Sites}

In this study, the selected research locations were 15 th, 19th, 20th, 21st and 22nd DKI Elementary Schools. The determination of the research location is based on several considerations as follows:

a. The State Elementary School has facilities and infrastructure that support research.

b. The State Elementary School is very strategically located for research implementation.

\section{Population}

The population in this study are teachers, students, and 
parents who are in 15th, 19th, 20th, 21st and 22nd DKI Elementary Schools.

\section{Sampling Technique}

Researchers used a non-random sampling method. In taking this sample the researchers processed 150 questionnaires out of 540 questionnaires which were distributed to teachers, parents, and students, consisting of:

a. 60 questionnaires out of 180 total questionnaires distributed to teachers.

b. 40 questionnaires out of 180 total questionnaires distributed to parents.

c. 50 questionnaires out of 180 total questionnaires distributed to students.

\section{Research Instruments}

This study uses a questionnaire as a research instrument to obtain the results of the reliability and validity as well as effective and efficient time. The questionnaire is used as the main data collection tool to measure effectiveness.

The questions in this questionnaire were compiled by researchers in a systematic and structured approach to closed and semi-open questions. Where for closed questions the answers provided have been determined beforehand by researchers and respondents were not allowed to provide other answers. This study uses a Likert scale which has the following values:

Table1. Scoring Table

\begin{tabular}{|c|c|}
\hline Scoring Classification & Score \\
\hline Strongly Agree & 5 \\
\hline Agree & 4 \\
\hline Enough & 3 \\
\hline Disagree & 2 \\
\hline Strongly Disagree & 1 \\
\hline
\end{tabular}

However, researchers only use up to 4 only and eliminate scores of 3 because of the tendency of Indonesians to choose a value of 3 which will cause the assessment to be unfavorable.

\section{Data Collection Technique}

The data that the researcher wants to obtain is quantitative and qualitative. Because of that researcher, the data collection technique used in this study is by collecting primary and secondary data.

\section{Data Processing Techniques}

Analysis of the data of this study used a validation test with a t-test. Descriptive data analysis is processed by providing manual coding of primary data derived from questionnaires. A tabulation table is made, and then the frequency table is arranged for each category of respondents and each of the questions.

Dependent sample t-test, often termed Paired Sample t-Test, is a type of statistical test that aims to compare the average of two groups that are in pairs [8]. Paired samples can be interpreted as a sample with the same subject but experience 2 different treatments or measurements, namely measurements before and after treatment [9].

The requirements for the type of Paired Sample t-Test are:

a. Data is normally distributed

b. The two data groups are dependent (interconnected or paired)

c. The type of data used is numeric and categorical (two groups).

The t-test formula used for paired samples is [10]:

$$
\mathrm{t}=\frac{\bar{x}_{1}-\bar{x}_{2}}{\frac{s_{1}{ }^{2}}{n_{1}}+\frac{s_{2}{ }^{2}}{n_{2}}-2 r\left(\frac{s_{1}}{\sqrt{n_{1}}}\right)\left(\frac{s_{2}}{\sqrt{n_{1}}}\right)}
$$

where:

$$
\begin{aligned}
& \mathrm{x}_{1}=\text { Sample average } 1 \\
& \mathrm{x}_{2}=\text { Sample mean } 2 \\
& \mathrm{~s}_{1}=\text { Standard sample deviation } 1 \\
& \mathrm{~s}_{2}=\text { Standard sample deviation } 2 \\
& \mathrm{~s}_{1}{ }^{2}=\text { Sample variance } 1 \\
& \mathrm{~s}_{2}{ }^{2}=\text { Sample variance } 2 \\
& \mathrm{r}=\text { Correlation between two samples }
\end{aligned}
$$

According to formula (1), there is a variable $\mathrm{x}$ as the data used by the sample. In this research, $x$ is the student's grade, so $\mathrm{x}_{1}$ is the student's average grade before implementing GOES, and $\mathrm{x}_{2}$ is the student's average grade after applying GOES.

Here is a picture of the t-region test curve: 


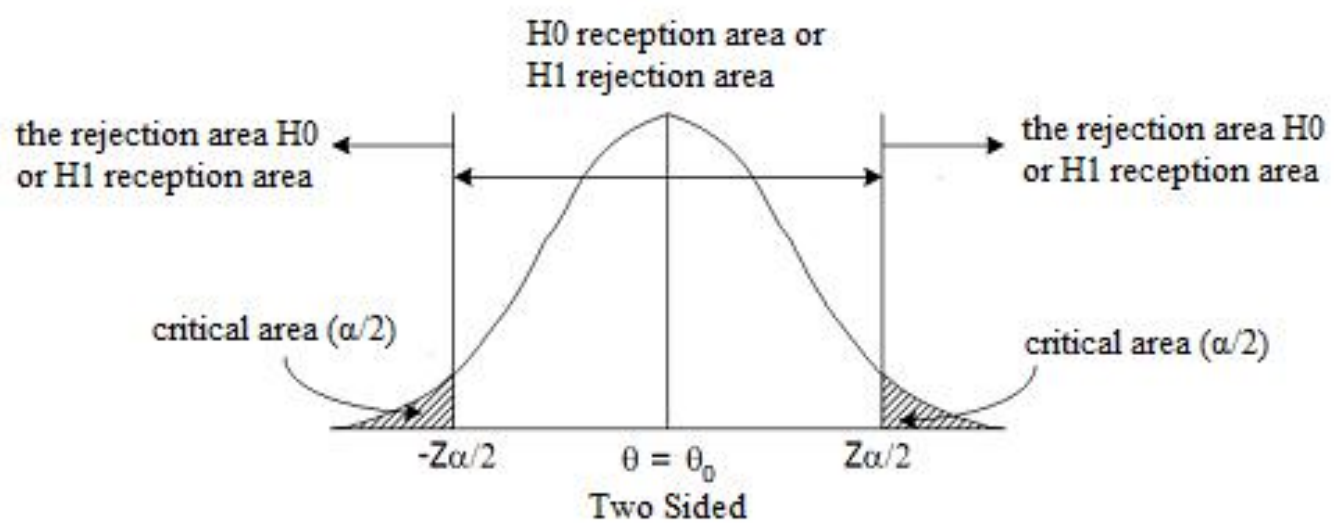

Figure 3. Curve the area of the t-test results [11]

Calculation of the t- test will result in a decision. The decision rules of the t-test are:

a. For correlations $\mathrm{X}_{1}$ and $\mathrm{X}_{2}$ are:

1. If $\alpha=0.05$ is smaller or equal to sig. or $\left[\alpha=0.05 \leq \mathrm{Sig}\right.$.] then $\mathrm{H}_{0}$ is accepted and $\mathrm{H}_{1}$ is rejected.

2. If $\alpha=0.05$ is greater or equal to sig. or [ $\alpha=0.05 \geq \mathrm{Sig}$.] then H1 is accepted and H0 is rejected.

b. For the t-test is:

1. If tarithmetic $\leq \mathrm{ttable}$ then $\mathrm{H} 0$ is accepted and $\mathrm{H} 1$ is rejected

2. If tarithmetic $\geq$ ttable then $\mathrm{H} 1$ is accepted and $\mathrm{H} 0$ is rejected

Below is the table for t-test:

Table2. Presentation table of t-test distribution

\begin{tabular}{|c|c|c|c|c|c|c|c|}
\hline $\mathrm{Pr}$ & $\begin{array}{l}0.25 \\
0.50\end{array}$ & $\begin{array}{l}0.10 \\
0.20 \\
\end{array}$ & $\begin{array}{l}0.05 \\
0.10 \\
\end{array}$ & $\begin{array}{l}0.025 \\
0.050\end{array}$ & $\begin{array}{l}0.01 \\
0.02\end{array}$ & $\begin{array}{l}0.005 \\
0.010\end{array}$ & $\begin{array}{l}0.001 \\
0.002 \\
\end{array}$ \\
\hline 1 & 1.00000 & 3.07768 & 6.31375 & 12.70620 & 31.82052 & 63.65674 & 318.30884 \\
\hline 2 & 0.81650 & 1.88562 & 2.91999 & 4.30265 & 6.96456 & 9.92484 & 22.32712 \\
\hline 3 & 0.76489 & 1.63774 & 2.35336 & 3.18245 & 4.54070 & 5.84091 & 10.21453 \\
\hline 4 & 0.74070 & 1.53321 & 2.13185 & 2.77645 & 3.74695 & 4.60409 & 7.17318 \\
\hline 5 & 0.72669 & 1.47588 & 2.01505 & 2.57058 & 3.36493 & 4.03214 & 5.89343 \\
\hline 115 & 0.67663 & 1.28896 & 1.65821 & 1.98081 & 2.35921 & 2.61926 & 3.16262 \\
\hline 116 & 0.67661 & 1.28889 & 1.65810 & 1.98063 & 2.35892 & 2.61888 & 3.16198 \\
\hline 117 & 0.67659 & 1.28883 & 1.65798 & 1.98045 & 2.35864 & 2.61850 & 3.16135 \\
\hline 118 & 0.67657 & 1.28877 & 1.65787 & 1.98027 & 2.35837 & 2.61814 & 3.16074 \\
\hline 119 & 0.67656 & 1.28871 & 1.65776 & 1.98010 & 2.35809 & 2.61778 & 3.16013 \\
\hline 120 & 0.67654 & 1.28865 & 1.65765 & 1.97993 & 2.35782 & 2.61742 & 3.15954 \\
\hline
\end{tabular}

Source : [11]

\section{Results}

Researchers used a non-random sampling method. In taking this sample the researchers processed 120 questionnaires out of 500 questionnaires which were distributed to teachers, parents, and students, consisting of:

a. 50 questionnaires out of 180 total questionnaires distributed to teachers.

b. 30 questionnaires out of 180 total questionnaires distributed to parents.

c. 40 questionnaires out of 180 total questionnaires distributed to students.

With hypotheses $\mathrm{H}_{0}$ and $\mathrm{H}_{1}$ are as follows:

$\mathrm{H}_{1}=$ There is a significant effect using the GOES application

$\mathrm{H}_{0}=$ There is no significant effect using the GOES application 
Below is data generated from 120 questionnaires out of 500 total questionnaires distributed:

Table 3. Questionnaire results table

\begin{tabular}{|c|c|c|c|c|c|}
\hline Data & Before & After & Data & Before & After \\
\hline $\mathbf{1}$ & 75 & 85 & $\mathbf{6 1}$ & 75 & 75 \\
\hline $\mathbf{2}$ & 80 & 90 & $\mathbf{6 2}$ & 80 & 85 \\
\hline $\mathbf{3}$ & 65 & 75 & $\mathbf{6 3}$ & 70 & 80 \\
\hline $\mathbf{4}$ & 70 & 75 & $\mathbf{6 4}$ & 90 & 95 \\
\hline $\mathbf{5}$ & 75 & 75 & $\mathbf{6 5}$ & 70 & 75 \\
\hline $\mathbf{6}$ & 80 & 90 & $\mathbf{6 6}$ & 75 & 85 \\
\hline $\mathbf{7}$ & 65 & 75 & $\mathbf{6 7}$ & 80 & 90 \\
\hline $\mathbf{8}$ & 80 & 75 & $\mathbf{6 8}$ & 65 & 75 \\
\hline $\mathbf{9}$ & 90 & 90 & $\mathbf{6 9}$ & 70 & 75 \\
\hline $\mathbf{1 0}$ & 75 & 70 & $\mathbf{7 0}$ & 75 & 75 \\
\hline $\mathbf{1 1}$ & 60 & 65 & $\mathbf{7 1}$ & 80 & 90 \\
\hline $\mathbf{1 2}$ & 70 & 75 & $\mathbf{7 2}$ & 65 & 70 \\
\hline
\end{tabular}

Table 3. continue

\begin{tabular}{|c|c|c|c|c|c|}
\hline 13 & 75 & 85 & 73 & 80 & 85 \\
\hline 14 & 70 & 65 & 74 & 90 & 95 \\
\hline 15 & 80 & 95 & 75 & 75 & 70 \\
\hline 16 & 65 & 65 & 76 & 60 & 65 \\
\hline 17 & 75 & 80 & 77 & 70 & 75 \\
\hline 18 & 70 & 80 & 78 & 75 & 85 \\
\hline 19 & 80 & 90 & 79 & 70 & 65 \\
\hline 20 & 65 & 60 & 80 & 80 & 95 \\
\hline 21 & 75 & 75 & 81 & 75 & 85 \\
\hline 22 & 80 & 85 & 82 & 80 & 90 \\
\hline 23 & 70 & 80 & 83 & 65 & 75 \\
\hline 24 & 90 & 95 & 84 & 70 & 75 \\
\hline 25 & 70 & 75 & 85 & 75 & 75 \\
\hline 26 & 75 & 85 & 86 & 80 & 90 \\
\hline 27 & 80 & 90 & 87 & 65 & 75 \\
\hline 28 & 65 & 75 & 88 & 80 & 75 \\
\hline 29 & 70 & 75 & 89 & 90 & 90 \\
\hline 30 & 75 & 75 & 80 & 75 & 70 \\
\hline 31 & 80 & 90 & 91 & 60 & 65 \\
\hline 32 & 65 & 70 & 92 & 70 & 75 \\
\hline 33 & 80 & 85 & 93 & 75 & 85 \\
\hline 34 & 90 & 95 & 94 & 70 & 65 \\
\hline 35 & 75 & 70 & 95 & 80 & 95 \\
\hline 36 & 60 & 65 & 96 & 65 & 65 \\
\hline 37 & 70 & 75 & 97 & 75 & 80 \\
\hline 38 & 75 & 85 & 98 & 70 & 80 \\
\hline 39 & 70 & 65 & 99 & 80 & 90 \\
\hline 40 & 80 & 95 & 100 & 65 & 60 \\
\hline 41 & 75 & 85 & 101 & 75 & 75 \\
\hline 42 & 80 & 90 & 102 & 80 & 85 \\
\hline 43 & 65 & 75 & 103 & 70 & 80 \\
\hline 44 & 70 & 75 & 104 & 90 & 95 \\
\hline 45 & 75 & 75 & 105 & 70 & 75 \\
\hline 46 & 80 & 90 & 106 & 75 & 85 \\
\hline
\end{tabular}




\begin{tabular}{|l|l|l|l|l|l|}
\hline $\mathbf{4 7}$ & 65 & 75 & $\mathbf{1 0 7}$ & 80 & 90 \\
\hline $\mathbf{4 8}$ & 80 & 75 & $\mathbf{1 0 8}$ & 65 & 75 \\
\hline $\mathbf{4 9}$ & 90 & 90 & $\mathbf{1 0 9}$ & 70 & 75 \\
\hline $\mathbf{5 0}$ & 75 & 70 & $\mathbf{1 1 0}$ & 75 & 75 \\
\hline $\mathbf{5 1}$ & 60 & 65 & $\mathbf{1 1 1}$ & 80 & 90 \\
\hline $\mathbf{5 2}$ & 70 & 75 & $\mathbf{1 1 2}$ & 65 & 70 \\
\hline $\mathbf{5 3}$ & 75 & 85 & $\mathbf{1 1 3}$ & 80 & 85 \\
\hline $\mathbf{5 4}$ & 70 & 65 & $\mathbf{1 1 4}$ & 90 & 95 \\
\hline $\mathbf{5 5}$ & 80 & 95 & $\mathbf{1 1 5}$ & 75 & 70 \\
\hline $\mathbf{5 6}$ & 65 & 65 & $\mathbf{1 1 6}$ & 60 & 65 \\
\hline $\mathbf{5 7}$ & 75 & 80 & $\mathbf{1 1 7}$ & 70 & 75 \\
\hline $\mathbf{5 8}$ & 70 & 80 & $\mathbf{1 1 8}$ & 75 & 85 \\
\hline $\mathbf{5 9}$ & 80 & 90 & $\mathbf{1 1 9}$ & 70 & 65 \\
\hline $\mathbf{6 0}$ & 65 & 60 & $\mathbf{1 2 0}$ & 80 & 95 \\
\hline
\end{tabular}

From the above results, a t-test was carried out and the following output was produced:

a. Paired samples statistics table results

Table 4. Paired samples statistics table on the results of the questionnaire

\begin{tabular}{|c|c|c|c|c|c|}
\hline \multicolumn{6}{|c|}{ Paired Samples Statistics } \\
\hline & & Mean & $\mathrm{N}$ & Std. Deviation & Std. Error Mean \\
\hline \multirow{2}{*}{ Pair 1} & $\begin{array}{c}\text { Effectiveness Before using the GOES } \\
\text { App }\end{array}$ & 74.00 & 120 & 7.379 & .674 \\
\hline & $\begin{array}{c}\text { Effectiveness After using the GOES } \\
\text { App }\end{array}$ & 79.13 & 120 & 9.716 & .887 \\
\hline
\end{tabular}

The table above shows the average difference between teaching and learning activities before using the GOES application $\left(\mathrm{X}_{1}\right)$ is 74 with the case being analyzed at 120 , the standard deviation is 7,379 . Whereas after using the GOES application $\left(\mathrm{X}_{2}\right)$ of 79.13 with a standard deviation of 9,716

b. Paired samples correlations table results

Table 5. Paired samples correlations table questionnaire results

\begin{tabular}{|c|c|c|c|c|}
\hline \multicolumn{5}{|c|}{ Paired Samples Correlations } \\
\hline & & $\mathrm{N}$ & Correlation & Sig. \\
\hline air 1 & $\begin{array}{l}\text { Effectiveness Before using the GOES App \& } \\
\text { Effectiveness After using the GOES App }\end{array}$ & 120 & .814 & .000 \\
\hline
\end{tabular}

Paired samples correlations table shows the magnitude of the correlation between $\mathrm{X}_{1}$ and $\mathrm{X}_{2}$ that is equal to 0.814 with a significance level of 0 . Apparently, $\alpha=0.05$ is greater than the value of Sig or [0.05>0], then $\mathrm{H}_{1}$ is accepted and $\mathrm{H}_{0}$ is rejected, meaning there is a change in activity teaching and learning after using the GOES application.

c. Paired Samples Test table results

Table 6. Paired Samples Test Table questionnaire results

\begin{tabular}{|c|c|c|c|c|c|c|c|c|c|}
\hline \multicolumn{10}{|c|}{ Paired Samples Test } \\
\hline & & \multicolumn{5}{|c|}{ Paired Differences } & \multirow[t]{3}{*}{$\mathrm{t}$} & \multirow[t]{3}{*}{ df } & \multirow[t]{3}{*}{ Sig. (2-tailed) } \\
\hline & & \multirow[t]{2}{*}{ Mean } & \multirow[t]{2}{*}{$\begin{array}{c}\text { Std. } \\
\text { Deviation }\end{array}$} & \multirow[t]{2}{*}{$\begin{array}{l}\text { Std. Error } \\
\text { Mean }\end{array}$} & \multicolumn{2}{|c|}{$\begin{array}{c}95 \% \text { Confidence Interval } \\
\text { of the Difference }\end{array}$} & & & \\
\hline & & & & & Lower & Upper & & & \\
\hline Pair 1 & $\begin{array}{l}\text { Effectiveness Before } \\
\text { using the GOES App } \\
\text { - Effectiveness After } \\
\text { using the GOES App }\end{array}$ & -5.125 & 5.668 & .517 & -6.150 & -4.100 & -9.905 & 119 & .000 \\
\hline
\end{tabular}

The Paired Samples Test table shows at taritmaetic of $-9,905$ with a Sig level (2-tailed) $=0,000$ and $\mathrm{df}=\mathrm{N}-1=$ $120-1=119$ so the value of table $=-1.98010$ at the significance level $[\alpha=0.05]$. It turns out that taritmaetic $>$ table then $\mathrm{H}_{1}$ is accepted and $\mathrm{H}_{0}$ is rejected, meaning there is a change in teaching and learning activities after using the GOES application. 


\section{Conclusions}

Based on data generated from 120 questionnaires out of 500 total questionnaires distributed with hypotheses $\mathrm{H}_{0}$ and $\mathrm{H}_{1}$ are as follows:

$\mathrm{H}_{1}=$ There is a significant influence using the GOES

application

$\mathrm{H}_{0}=$ There is no significant effect using the GOES

application

A t-test was carried out which produced:

a. For correlations $X_{1}$ and $X_{2}$, the value $\alpha=0.05$ is greater or equal to sig. or $[\alpha=0.05 \geq 0]$ then $\mathrm{H}_{1}$ is accepted and $\mathrm{H}_{0}$ is rejected.

b. For t-test is the value of tarithmetic $\geq$ ttable then $\mathrm{H} 1$ is accepted and $\mathrm{H} 0$ is rejected

Thus it can be concluded that there is a significant effect using the GOES application. The GOES application provides a positive influence on teaching and learning activities in the classroom. Students can still get learning material even though they cannot attend class. Parents can easily help students with their work. The GOES application can help the teacher deliver the material, and it can also be a liaison between parents and teachers at school.

For future research, this application can be added to the list of attendance of students and teachers, so that it can be a monitoring of the Principal about the condition of teaching and learning activities. Additional assessments can also be given so that parents can find out student learning outcomes.

\section{Acknowledgments}

Appreciation and thanks to the Ministry of Research and Technology which has funded the activities of University Basic Research in 2018-2019 with the title: "Designing Guide Application Objective Elementary School (Goes) System for Optimizing Elementary School Learning". Thanks also to the Indraprasta University Research Institute and Community Service PGRI for helping with this research activity through the Research Contract Number: 30/AKM/MONOPNT/2019, tanggal 27 Maret 2019 and LPPM Indraprasta University PGRI Research Agreement / Contract Number: 0504 / SKP.LT / LPPM / UNINDRA / III / 2019, March 29, 2019.

\section{REFERENCES}

[1] A. Putu Desiana Wulaning, "Analisis Pengukuran Tingkat Efektivitas dan Efisiensi Sistem Informasi Manajemen Surat STIKOM Bali,” J. Sist. Dan Inform., vol. 11, no. No. 2, 2017.

[2] Basil S. Georgopoulus and Arnold S. Tannenbaum. A
Study of Organizational Effectiviness. Policies, Decisions and Organizatons, Publisher: Meredith Corporation, Editors: F. Lynden, G. Shipman, M. Kroll. 2016.

[3] T. H. Handoko, Manajemen. Yogyakarta: BPFE, 2012.

[4] Devung, Pengantar Ilmu administrasi dan Manajemen. Jakarta: Depdikbud, 2012.

[5] Danny Samson, Richard L. Daft, Timothy Donnet, Management with Student Resource Access 12 Months . 4th Asia Edition, 2017

[6] Starawaji, Corporate Social Responsibility dalam Praktek di Indonesia. Jakarta: PT Elex Media Komputindo, 2009.

[7] Fraser Health Authority, "Quantitative Research Methods and Tools." 2011.

[8] Douglas C. M and George C. R, Applied Statistics and Probability for Engineers 3rd Edition. John Wiley \& Sons, Inc, 2003.

[9] B. Gerald, "A Brief Review of Independent, Dependent and One Sample t-test," Int. J. Appl. Math. Theor. Phys., vol. 4, no. 2, p. 50, 2018.

[10] B. Derrick, D. Toher, B. Russ, and P. White, "Test statistics for the comparison of means for two samples that include both paired and independent observations," J. Mod. Appl. Stat. Methods, vol. 16, no. 1, pp. 137-157, 2017.

[11] B. Johnson and L. Cristensen, Education Reseach Quantitave, Qualitative, and Mixer Approacher. 2008. 